Webology, Volume 17, Number 1, June, 2020

\begin{tabular}{|l|l|l|l|}
\hline Home & Table of Contents & Titles \& Subject Index & Authors Index \\
\hline
\end{tabular}

\title{
Environmental Literacy and Accountability of Undergraduate Students of Medical Sciences
}

\section{Roghayeh Ershad Sarabi}

Assistant Professor, Department of Health Information Technology, School of Health Management and Medical Informatics, Kerman University of Medical Sciences, Kerman, Iran. ORCID: 0000-0001-8926-0156. E-mail: a.ershadsarabi@gmail.com

\section{Mohmmadhiwa Abdekhoda*}

*Corresponding Author, Associate Professor, Department of Medical Library and Information Sciences, School of Health Management and Medical Informatics, Tabriz University of Medical Sciences. Iranian Center of Excellence in Health Management (ICEHM), School of Management and Medical Informatics, Tabriz University of Medical Sciences, Tabriz, Iran. ORCID: 00000002-1797-8916. E-mail: abdekhodam@tbzmed.ac.ir

\section{Afsaneh Dehnad \\ Associate Professor, English Language Department, School of Health Management and Information Sciences, Center for Educational Research in Medical Sciences (CERMS), Iran University of Medical Sciences, Tehran, Iran. ORCID: 0000-0001-5731-8894. E-mail: dehnad.a@iums.ac.ir}

\section{Golnoosh Khajouei}

$\mathrm{PhD}$ Candidate, Department of Civil and Environmental Engineering, West Virginia University, Morgantown 26505, USA. ORCID: 0000-0003-0624-1166. E-mail: golnoosh.khajoei@ gmail.com

Received January 18, 2020; Accepted June 20, 2020 


\begin{abstract}
This was a descriptive-analytical study which was conducted to investigate the knowledge, attitude and accountability of students towards the environment. The study population consisted of undergraduate students of Kerman University of Medical Sciences, 210 of them were selected by using simple and accessible random sampling method. The participants' knowledge of the environment was at low level, but their accountability about environmental issues was relatively high. Participants had a good attitude towards environmental issues and protection. Participants were largely concerned about environmental issues conveyed to them via parents' perspective. More than 50 percent of them were active in environmental protection activities. Other findings showed that participants obtained most of their environmental information from the Internet, television, newspapers, magazines and books, respectively. According to linear regression analysis, environmental knowledge score was not significantly correlated with variables such as sex, age, residence, and education of their parents. Therefore, the current study confirms the impact of education on the students' knowledge, attitude, and accountability towards the environment, and that the source of knowledge for most of the students is through the Internet, the development of university educational programs, and curriculum especially in the form of online learning is recommended.
\end{abstract}

\title{
Keywords
}

Environmental knowledge; Environmental accountability; Environmental literacy; Students; Attitudes; Environmental studies

\section{Introduction}

The environment is an inseparable part of human life, but today it faces serious threats due to unlimited use of natural resources which are left without any essential protection. Pollution of the climate and soil, destruction of forests, production and consumption of poisons and destruction of the atmosphere, are known as global humanitarian challenges (Pujianti, Munandar, \& Surakusumah, 2018). Considering the impact of environmental problems on the lives of people, a plan to overcome the existing problems and prevent the emergence of new problems requires awareness, education and general environmental knowledge. This is typically referred to as environmental literacy. It is widely believed that we will be able to overcome environmental hazards by understanding the importance of the environment and contributing to the development of environmental literacy (Wardani, Karyanto, \& Ramli, 2018). Based on this assumption, the environment is associated with three concepts of nature, environmental issues and a sustainable solution to existing problems (Barghi, Najafi, \& Rajabi, 2017). 
In assessing the pertinent literacy, individuals' knowledge, skills and willingness to participate in civil activities, as well as their awareness of their duty to protect the environment should be addressed (Wong, Afandi, Ramachandran, Kunasekaran, \& Chan, 2018). These characteristics, which enable citizens to maintain environmental sustainability, are attributed to four key components of environmental literacy: knowledge, impact, cognitive, and behavioral skills (Hollweg et al., 2011).

Evaluating environmental literacy provides important information that can be used as a basis for planning the development of the curriculum of an environmental education program at various levels of education. There are a few research studies and evaluation tools in this area, and environmental research has largely focused on specific issues such as pollution of water or air in a given geographical area, and environmental behavior. Moreover, the need for environmental literacy assessment is recommended by literature (Daniš, 2013).

The evaluation of the effect of formal and informal education, as a component of environmental literacy, on the knowledge of individuals in different groups of the society has attracted the attention of researchers, some of whom have highlighted the evaluation of students' environmental literacy (Owusu, Ossei Kwakye, Welbeck, \& Ofori, 2017; Pe'er, Goldman, \& Yavetz, 2007).

Considering that students are the future makers of science, technology and management of a society and their attitudes and behaviors affect the formation of public culture, knowledge management for development of environmental literacy should be taken into consideration (Zhang, Ming-Da, Dan, Ying, \& Na, 2016). The findings of this research are important because in addition to the assessment of environmental literacy of undergraduate students of a medical university, the relationship between health literacy and environmental literacy is addressed. This could also contribute to awareness raising on environmental issues among undergraduate students of medical universities (Chepesiuk, 2007). Based on the findings of a recent study at a university in Iran, students' environmental literacy was very low, although they were sensitive to environmental issues. According to similar studies, carried out in other universities of Iran, aggregation of the findings can lead to the national recognition of students' literacy in the country, in order to design appropriate curriculum related to environmental education programs (Veisi, Lacy, Mafakheri, \& Razaghi, 2018).

In this regard, the aim of this study was to evaluate the level of environmental literacy of undergraduate students of Kerman University of Medical Sciences. In this research, four components of environmental literacy including knowledge, attitude, sensitivity, behavior and the source of knowledge were assessed. 


\section{Materials and Methods}

This descriptive-analytic study was carried out to assess the environmental literacy of undergraduate students studying at Kerman University of Medical Sciences. The population of the study consisted of 400 students studying in the schools of health, allied medicine, and management and information sciences. From this population, 210 students were selected by using Krejcie and Morgan (1970) table and convenient sampling model.

The data collection instrument was a questionnaire designed on the basis of the literature review. The validity of the questionnaire was confirmed by the faculty members' comments of health information management. For reliability of the questionnaire, we used internal reliability method, which was higher than 0.8 for Cronbach's alpha.

The questionnaire evaluated various aspects of environmental literacy with 64 questions in seven sections including demographic information, environmental awareness, environmental knowledge, environmental accountability, environmental sensitivity, and environmental responsibility. The questionnaire was distributed among students of each discipline through an accessible sample method. Out of 220 questionnaires distributed, 179 were completed and returned. Then, the data were coded and analyzed by using appropriate tests in the SPSS software.

\section{Result}

As the findings of this table indicate, more than 50 percent of the participants were male and the other half was female students. About 60 percent of the participants lived in detached houses. Their mothers largely had a high school diploma degree or lower whereas 60 percent of their fathers had high school diploma or higher. Their mothers were mainly housewives while 50 percent of their fathers were freelance workers. Other findings showed that the average age of the participants was 17.22 years.

Table 1. Participants' demographic information

\begin{tabular}{|c|l|c|c|}
\hline Variable name & \multicolumn{1}{|c|}{ Variable level } & Frequency & Percentage \\
\hline \multirow{4}{*}{ Gender } & Male & 117 & 65.4 \\
\cline { 2 - 4 } & Female & 62 & 34.6 \\
\hline \multirow{4}{*}{ Residential } & the apartment & 58 & 32.4 \\
\cline { 2 - 4 } & Villa & 108 & 60.3 \\
\cline { 2 - 4 } & City Side Apartment & 3 & 1.7 \\
\cline { 2 - 4 } & Villa on the outskirts of town & 7 & 3.9 \\
\hline \multirow{5}{*}{ Mother's education } & illiterate & 4 & 2.2 \\
\cline { 2 - 4 } & Elementary & 46 & 25.7 \\
\cline { 2 - 4 } & Diploma & 76 & 42.5 \\
\cline { 2 - 4 } & Masters & 39 & 21.8 \\
\cline { 2 - 4 } & Senior & 2 & 6.1 \\
\cline { 2 - 4 } & Doctor & 1.1 \\
\hline
\end{tabular}




\begin{tabular}{|c|l|c|c|}
\hline \multirow{4}{*}{ Father's education } & Illiterate & 7 & 3.9 \\
\cline { 2 - 4 } & Elementary & 40 & 22.3 \\
\cline { 2 - 4 } & Diploma & 61 & 34.1 \\
\cline { 2 - 4 } & Masters & 55 & 30.7 \\
\cline { 2 - 4 } & Senior & 14 & 7.8 \\
\cline { 2 - 4 } & Doctor & 1 & .6 \\
\hline \multirow{5}{*}{ Mother's job } & Retired & 4 & 2.3 \\
\cline { 2 - 4 } & Employee & 5 & 2.8 \\
\cline { 2 - 4 } & Housewife & 105 & 58.7 \\
\cline { 2 - 4 } & Teacher & 6 & 3.4 \\
\cline { 2 - 4 } & Free & 31 & 17.3 \\
\hline \multirow{5}{*}{ Father's job } & Free & 88 & 49.1 \\
\cline { 2 - 4 } & Retired & 28 & 15.6 \\
\cline { 2 - 4 } & Chef & 1 & .6 \\
\cline { 2 - 4 } & Deceased & 4 & 2.2 \\
\cline { 2 - 4 } & Employee & 14 & 7.8 \\
\cline { 2 - 4 } & Farmer & 3 & 1.7 \\
\cline { 2 - 4 } & Military & 1 & .6 \\
\cline { 2 - 4 } & Nurse & 2 & .6 \\
\cline { 2 - 4 } & Teacher & & 2.2 \\
\cline { 2 - 4 } & Manual worker & 2 & \\
\hline
\end{tabular}

Table 2 shows the mean and standard deviation of respondents' scores in 5 parts of the environmental knowledge. As it is seen in this table, the range of scores of environmental knowledge, environmental accountability, environmental sensitivity, environmental responsibility, and environmental attitudes were 0-16, 12-60, 19-95, 6-30, and 10-50, respectively.

Table 2. Mean and standard deviation of scores for responding to dimensions of environmental knowledge

\begin{tabular}{|l|c|c|c|c|c|}
\hline & $\begin{array}{c}\text { Number of } \\
\text { respondents }\end{array}$ & $\begin{array}{c}\text { Average } \\
\text { score }\end{array}$ & $\begin{array}{c}\text { standard } \\
\text { deviation } \\
\text { score }\end{array}$ & $\begin{array}{c}\text { Lowest } \\
\text { score }\end{array}$ & $\begin{array}{c}\text { Highest } \\
\text { score }\end{array}$ \\
\hline Environmental knowledge & 179 & 6.07 & 2.14 & 0 & $\mathbf{1 0}$ \\
\hline Concern about the environment & 179 & 44.85 & 9.53 & 12 & $\mathbf{6 0}$ \\
\hline Environmental sensitivity & 179 & 74.94 & 10.73 & 42 & \\
\hline Environmental responsibility & 178 & 18.57 & 4.03 & 4 & $\mathbf{2 5}$ \\
\hline Attitude towards the environment & 178 & 34.36 & 4.88 & 17 & $\mathbf{5 0}$ \\
\hline
\end{tabular}

The findings of this table illustrate that in the field of environmental knowledge, if the correct answer to all questions are considered, the lowest score would be zero and the maximum score 16. Given that the mean score of knowledge is 6.07 , it can be said that knowledge about the environment in the participants is low in this study. Regarding environmental concern, with a score of 12-60 and an average of 85.44 , it can be said that the participants' concerns are high in relation to the environment. Findings in the context of environmental sensitivity suggest that participants are sensitive to environmental issues, with a sensitivity score of 95-199 and an 
average of 94.94. Other findings indicate that participants' environmental responsibility is favorable with an average of 18.57. The findings also indicate that the participants have a positive attitude toward environmental issues and are supportive in this regard.

Table 3 shows the level of concern and attitude of students' parents towards environmental issues. As the findings of this table show, most parents are worried about their environmental accountability, and more than 50 percent of them are active in protecting the environment.

Table 3. Participants 'parents' attitudes toward the environment and its protection

\begin{tabular}{|c|c|c|c|}
\hline Question & Variable levels & Frequency & Percent \\
\hline How concerned do & Too much & 77 & 43.0 \\
\cline { 2 - 4 } you think parents & Much & 32 & 17.9 \\
\cline { 2 - 4 } $\begin{array}{c}\text { are about } \\
\text { environmental } \\
\text { problems? }\end{array}$ & No idea & 42 & 23.5 \\
\cline { 2 - 4 } & Low & 23 & 12.8 \\
\cline { 2 - 4 } & Very little & 4 & 2.2 \\
\hline \multirow{3}{*}{$\begin{array}{c}\text { Parents' activity in } \\
\text { protecting the } \\
\text { environment }\end{array}$} & Too much & 48 & 26.8 \\
\cline { 2 - 4 } & Much & 30 & 16.8 \\
\cline { 2 - 4 } & No idea & 57 & 31.8 \\
\cline { 2 - 4 } & Low & 36 & 20.1 \\
\cline { 2 - 4 } & Very little & 5 & 2.8 \\
\hline
\end{tabular}

Table 4 shows the level of concern and awareness of the participants about environmental issues. The findings from this table show that over 70 percent of the participants are concerned about environmental issues. Also, about 60 percent of the participants reported their awareness of environmental issues "very much".

Table 4. Participants' concern and awareness about environmental issues

\begin{tabular}{|c|c|c|c|}
\hline Question & Variable levels & Frequency & Percent \\
\hline \multirow{3}{*}{$\begin{array}{c}\text { Concerns about } \\
\text { environmental } \\
\text { problems }\end{array}$} & Very much & 85 & 47.5 \\
\cline { 2 - 4 } & Much & 61 & 34.1 \\
\cline { 2 - 4 } & Low & 21 & 11.7 \\
\cline { 2 - 4 } & very little & 7 & 3.9 \\
\cline { 2 - 4 } & No worries & 3 & 1.7 \\
\hline \multirow{4}{*}{$\begin{array}{c}\text { Self-awareness about } \\
\text { environmental issues }\end{array}$} & Very much & 28 & 15.6 \\
\cline { 2 - 4 } & Much & 90 & 50.3 \\
\cline { 2 - 4 } & Low & 48 & 26.8 \\
\cline { 2 - 4 } & Very little & 7 & 3.9 \\
\cline { 2 - 4 } & I do not know & 4 & 2.2 \\
\hline
\end{tabular}

Table 5 shows the source of information on environmental issues. Based on the findings of this table, participants receive the information they need about environmental resources from the Internet, $\mathrm{TV}$, newspapers, magazines and books, respectively. 
Table 5. Information resources for participants on environmental issues

\begin{tabular}{|c|l|c|c|}
\hline Question & \multicolumn{1}{|c|}{ Variable levels } & Frequency & Percent \\
\hline \multirow{4}{*}{$\begin{array}{c}\text { Source of } \\
\text { information on } \\
\text { the environment }\end{array}$} & Newspaper, books, magazines & 7 & 3.9 \\
\cline { 2 - 4 } & Internet & 39 & 21.8 \\
\cline { 2 - 4 } & Television & 29 & 16.2 \\
\cline { 2 - 4 } & University and workplace & 3 & 1.7 \\
\cline { 2 - 4 } & Family & 3 & 1.7 \\
\cline { 2 - 4 } & Friends & 2 & 1.1 \\
\cline { 2 - 4 } & Several sources & 96 & 53.6 \\
\hline
\end{tabular}

Table 6 shows the results of linear regression analysis about the participants' knowledge scores and other variables. According to the findings, there was no significant relationship between knowledge score and gender, age, place of residence and level of mothers' and fathers' education.

Table 6. Linear regression analysis between participants' knowledge scores and other variables

\begin{tabular}{|l|c|c|c|}
\hline \multirow{2}{*}{ Variables } & \multicolumn{2}{|c|}{ Unstandardized Coefficients } & \multirow{2}{*}{ p-value } \\
\cline { 2 - 3 } & $\mathrm{B}$ & Std. Error & \\
\hline Constant & 5.965 & 1.611 & .000 \\
\hline Sex & .499 & .354 & .160 \\
\hline Age & -.004 & .045 & .936 \\
\hline Place of residence & .020 & .258 & .939 \\
\hline Mother's education & .285 & .228 & .214 \\
\hline Father's education & -0.286 & .167 & .088 \\
\hline
\end{tabular}

Table 7 shows the relationship between participants' knowledge of environmental issues. Spearman analysis was used to investigate the relationship between environmental knowledge variables with other variables such as concern, responsibility, sensitivity and attitude towards the environment. Based on this analysis, there was no significant statistical correlation between the environmental knowledge and the aforementioned variables. However, there was a nonsignificant positive relationship between knowledge scores and sensitivity and responsibility, and a non-significant negative relationship between knowledge and concern and attitude.

Table 7. Relationship between Dimensions of Knowledge of Participants on Environmental Issues

\begin{tabular}{|l|c|c|}
\hline \multicolumn{1}{|c|}{ Variables } & $\begin{array}{c}\text { correlation coefficient with } \\
\text { the knowledge score }\end{array}$ & p-value \\
\hline Allergy & .117 & .120 \\
\hline Responsibility & .007 & .927 \\
\hline Worries & -.045 & .550 \\
\hline Attitude & -.044 & .558 \\
\hline
\end{tabular}

Based on the results of this study, there was no significant correlation between environmental knowledge and sensitivity, attitude and behavior 


\section{Discussion}

The findings of this study showed that although environmental knowledge of the students was low with a mean score of 6.07, their concern about the environment was high with a mean score of 44.85. The students were also very sensitive to environmental issues with a score of 74.94. The students with an average score of 34.36 had a favorable attitude toward environmental issues and were supportive.

Other studies investigating similar issues have reported differing knowledge, attitudes, sensitivity, and behavior of students in the field of environment. The findings of the present study were in line with the results of a national study conducted by Liang in Taiwan in 2018(Liang et al., 2018). In his study, environmental literacy was assessed by approximately 3,000 undergraduate students from 70 colleges and universities in Taiwan. The results of the study showed that the level of knowledge and environmental behavior of students were below average and their attitudes were average. Similarly, the findings of our study showed that there was no significant relationship between students' knowledge and behavior and knowledge and attitude. Also, students' source of environmental information was obtained initially from the Internet and then from T.V. broadcasting services. Although the sample size of our study was much lower than that of the Liang's study in Taiwan, similar results from research indicate a crucial need for global environmental education programs (Liang et al., 2018).

The results of the Strovas' study, which examined the environmental literacy of 1912 undergraduate students at a US university, also showed that students had the highest scores on attitude assessment and the lowest on environmental knowledge and behavior. The results of the Strovas' study showed the significant relationship between gender, students' knowledge score, attitude and performance. He reported that score of knowledge was higher in male students whereas the score of attitude and behavior was higher in female students (Lloyd-Strovas, Moseley, \& Arsuffi, 2018).

In a study in Bangladesh in 2017, a researcher examined students' environmental knowledge with eight questions. The sample included 400 students from four selected universities. The results of the study, contrary to the results of our study, showed that the students' knowledge of the environment was high and the knowledge of students with a background in environmental education was significantly higher. As in our study, mass media has played an important role as a source of environmental data (Majumder, 2017).

In the 2017, Owusu investigated this topic with 620 undergraduate environmental students in Ghana. Based on the findings, the researcher has presented a model of students' environmental literacy that is in line with some of the results of our study. According to the model, increasing knowledge leads to a better attitude and better behavior towards the environment, although this relationship is not significant (Owusu et al., 2017). 
The results of our study are in line with other findings of other research studies conducted in Iran. In 2018, Weiss examined the knowledge, attitude, behavior, and sensitivity of 1068 students from various disciplines at one of Iran's largest universities, the results of which showed that students' knowledge was below average, but their attitudes, sensitivity, and behavior towards the environment were positive. In contrast to the present study, there was a significant relationship between environmental literacy and demographic characteristics of students in the study conducted by Veisi et al. (2018), They concluded that parents' education had a significant effect on students' environmental literacy.

The results of the present study were in contrast to Salehi's findings that evaluated the environmental literacy of 415 students from 7 Mazandaran universities in 2014. Based on the findings of that study, students reported high levels of environmental knowledge while their level of knowledge was different in different schools. Moreover, the participants reported that television was the most important source of acquiring environmental information (Salehi \& Pazokinejad, 2014).

\section{Conclusion}

Evaluation of information literacy of the students in this study showed that the environmental knowledge scores of most students were low. Comparison of the findings of the present study with previous studies in Iran and other countries shows that although students have positive attitudes and behavior towards environmental issues, their knowledge on this issue is below the average level. Given that research has confirmed the impact of education on young people's knowledge, attitude, behavior and sensitivity to the environment (Kibert, 2000; Majumder, 2017), the source of knowledge is often reported to be gained via the Internet(Liang et al., 2018). The development of university programs in general, and online programs in particular are recommended because evidence has shown that increasing students' knowledge will improve their attitude and subsequently promote their environmental behavior (Owusu et al., 2017).

After the Internet, mass media such as television have been the most important source of environmental knowledge(Majumder, 2017). Therefore, it is recommended to use this tool to increase students' parenting knowledge, attitude, and behavior in order to increase parental awareness and eventually students' environmental literacy (Rezaei, Shobeiri, Sarmadi, \& Larijani, 2018).

\section{References}

Barghi, H., Najafi, M., \& Rajabi, M. (2017). Evaluating environmental awareness, attitude, and performance in post-graduate students of Isfahan University and verifying their views on rural environment challenges. International Journal of Environmental Policy and Decision Making, 2(3), 179-195. 
Chepesiuk, R. (2007). Environmental literacy: knowledge for a healthier public. Environmental health perspectives, 115(10), A494-A499. DOI:10.1289/ehp.115-a494

Daniš, P. (2013). A new definition of environmental literacy and a proposal for its international assessment in PISA 2015. Envigogika, 8(4).

Hollweg, K. S., Taylor, J. R., Bybee, R. W., Marcinkowski, T. J., McBeth, W. C., \& Zoido, P. (2011). Developing a framework for assessing environmental literacy. Washington, DC: North American Association for Environmental Education.

Kibert, N. C. (2000). An analysis of the correlations between the attitude, behavior, and knowledge components of environmental literacy in undergraduate university students,[electronic resource]. University of Florida.

Liang, S.-W., Fang, W.-T., Yeh, S.-C., Liu, S.-Y., Tsai, H.-M., Chou, J.-Y., \& Ng, E. (2018). A Nationwide Survey Evaluating the Environmental Literacy of Undergraduate Students in Taiwan. Sustainability, 10(6), 1730.

Lloyd-Strovas, J., Moseley, C., \& Arsuffi, T. (2018). Environmental literacy of undergraduate college students: Development of the environmental literacy instrument (ELI). School Science and Mathematics, 118(3-4), 84-92.

Majumder, A. K. (2017). Assessments of environmental awareness among the some selective university students of Bangladesh. American Journal of Education and Information Technologies, 1, 38-42.

Owusu, G. M. Y., Ossei Kwakye, T., Welbeck, E. E., \& Ofori, C. G. (2017). Environmental literacy of business students in Ghana. International Journal of Sustainability in Higher Education, 18(3), 415-435.

Pe'er, S., Goldman, D., \& Yavetz, B. (2007). Environmental literacy in teacher training: Attitudes, knowledge, and environmental behavior of beginning students. The Journal of Environmental Education, 39(1), 45-59.

Pujianti, N., Munandar, A., \& Surakusumah, W. (2018). Environmental literacy in agriculture and coastal areas. Paper presented at the Journal of Physics: Conference Series.

Rezaei, M., Shobeiri, S. M., Sarmadi, M. R., \& Larijani, M. (2018). The evaluation of the effect of environmental programs of $\mathrm{Tv}$ on the Promotion of environmental awareness and attitude of students. Journal of Environmental Science and Technology, 20(2), 203-215.

Salehi, S., \& Pazokinejad, Z. (2014). An Analysis of Social Factors Influencing Students' Environmental Attitudes and Performance. Journal of Applied Sociology (1735-000X), 55(3).

Veisi, H., Lacy, M., Mafakheri, S., \& Razaghi, F. (2018). Assessing environmental literacy of university students: A case study of Shahid Beheshti University in Iran. Applied Environmental Education \& Communication, 1-18.

Wardani, R., Karyanto, P., \& Ramli, M. (2018). Analysis of high school students' environmental literacy. Paper presented at the Journal of Physics: Conference Series. 
Wong, C. A., Afandi, S. H. M., Ramachandran, S., Kunasekaran, P., \& Chan, J. K.-L. (2018). conceptualizing environmental literacy and factors affecting pro-environmental behaviour. International Journal of Business and Society, 19(S1), 128-139.

Zhang, W., Ming-Da, L., Dan, Y., Ying, Y., \& Na, H. (2016). Students' Environmental Literacy Survey and Public Environmental Education Countermeasures in Agricultural University. DEStech Transactions on Social Science, Education and Human Science (MESS).

\section{Bibliographic information of this paper for citing:}

Ershad Sarabi, R., Abdekhoda, M., Dehnad, A., \& Khajouei, G. (2020). "Environmental literacy and accountability of undergraduate students of medical sciences." Webology, 17(1), Article 216. Available at: http://www.webology.org/2020/v17n1/a216.pdf

Copyright ( 2020, Roghayeh Ershad Sarabi, Mohmmadhiwa Abdekhoda, Afsaneh Dehnad and Golnoosh Khajouei. 